\title{
Epidemiological characterisation of the first 785 SARS- CoV-2 Omicron variant cases in Denmark, December 2021
}

Laura Espenhain ${ }^{1}$, Tjede Funk ${ }^{1,2}$, Maria Overvad ${ }^{1}$, Sofie Marie Edslev ${ }^{3}$, Jannik Fonager ${ }^{4}$, Anna Cäcilia Ingham ${ }^{3}$, Morten

Rasmussen ${ }^{4}$, Sarah Leth Madsen ${ }^{5}$, Caroline Hjorth Espersen ${ }^{1}$, Raphael N. Sieber ${ }^{3}$, Marc Stegger ${ }^{3}$, Vithiagaran Gunalan ${ }^{4}$, Bartlomiej Wilkowski $i^{6,7}$, Nicolai Balle Larsen ${ }^{6}$, Rebecca Legarth ${ }^{1}$, Arieh Sierra Cohen 6 , Finn Nielsen ${ }^{8}$, Janni Uyen Hoa Lam ${ }^{8}$, Kjetil Erdogan Lavik ${ }^{8}$, Marianne Karakis ${ }^{8}$, Katja Spiess ${ }^{4}$, Ellinor Marving ${ }^{4}$, Christian Nielsen ${ }^{6,7}$, Christina Wiid Svarrer ${ }^{3}$, Jonas Bybjerg-Grauholm ${ }^{9}$, Stefan Schytte Olsen ${ }^{8}$, Anders Jensen ${ }^{6,7}$, Tyra Grove Krause ${ }^{10}$, Luise Müller ${ }^{1}$

1. Infectious Disease Epidemiology and Prevention, Statens Serum Institut, Copenhagen, Denmark

2. European Programme for Intervention Epidemiology Training (EPIET), European Centre for Disease Prevention and Control, (ECDC), Stockholm, Sweden

3. Department of Bacteria, Parasites and Fungi, Statens Serum Institut, Copenhagen, Denmark

4. Virus and Microbiological Special Diagnostics, Statens Serum Institut, Copenhagen, Denmark

5. COVID-19 tracing Unit, Danish Patient Safety Authority, Copenhagen, Denmark

6. TestCenter Denmark, Statens Serum Institut, Copenhagen, Denmark

7. Danish National Biobank, Statens Serum Institut, Copenhagen, Denmark

8. The Data integration and Analysis Secretariat, Statens Serum Institut, Copenhagen, Denmark

9. Congenital disorders, Statens Serum Institut, Copenhagen, Denmark

10. Epidemiological Infectious Disease Preparedness, Statens Serum Institut, Copenhagen, Denmark

Correspondence: Laura Espenhain (laes@ssi.dk)

Espenhain Laura, Funk Tjede, Overvad Maria, Edslev Sofie Marie, Fonager Jannik, Ingham Anna Cäcilia, Rasmussen Morten, Madsen Sarah Leth, Espersen Caroline Hjorth, Sieber Raphael N., Stegger Marc, Gunalan Vithiagaran, Wilkowski Bartlomiej, Larsen Nicolai Balle, Legarth Rebecca, Cohen Arieh Sierra, Nielsen Finn, Lam Janni Uyen Hoa, Lavik Kjetil Erdogan, Karakis Marianne, Spiess Katja, Marving Ellinor, Nielsen Christian, Wiid Svarrer Christina, Bybjerg-Grauholm Jonas, Olsen Stefan Schytte, Jensen Anders, Krause Tyra Grove, Müller Luise. Epidemiological characterisation of the first 785 SARS-CoV-2 Omicron variant cases in Denmark, December 2021. Euro Surveill. 2021;26(50):pii=2101146. https://doi.org/10.2807/1560-7917.ES.2021.26.50.21011462015;20(34):pii=30002. DOI: http://dx.doi. org/10.2807/1560-7917.ES.2015.20.34.30002

By 9 December 2021, 785 SARS-CoV-2 Omicron variant cases have been identified in Denmark. Most cases were fully $(76 \%)$ or booster-vaccinated $(7.1 \%)$; $34(4.3 \%)$ had a previous SARS-CoV-2 infection. The majority of cases with available information reported symptoms $(509 / 666 ; 76 \%)$ and most were infected in Denmark ( $588 / 644 ; 91 \%)$. One in five cases cannot be linked to previous cases, indicating widespread community transmission. Nine cases have been hospitalised, one required intensive care and no deaths have been registered.

On 26 November 2021, the World Health Organization designated the severe acute respiratory syndrome coronavirus 2 (SARS-CoV-2) Omicron variant (Phylogenetic Assignment of Named Global Outbreak (Pango) lineage designation B.1.1.529) a variant of concern [1]. Two days later, on 28 November 2021, the first two Omicron cases were identified in Denmark in travellers returning from South Africa (see detailed timeline in Table 1). By 9 December, a total of 785 Omicron cases have been registered in Denmark. The aim of this communication is to describe these first Danish cases to provide insights into the spread and early indications of severity.

\section{Surveillance of SARS-CoV-2 variants in Denmark}

An important pillar in the Danish coronavirus disease (COVID-19) response has been free and easy access to testing. Community testing is carried out in 'TestCenter Denmark' (TCDK), where every resident or visitor in Denmark can book an appointment (TCDK carried out more than $85 \%$ of all tests [2] and uses reverse transcription PCR (RT-PCR) for SARS-CoV-2 confirmation). Furthermore, testing is also carried out through referral mainly from general practitioners or hospitals as part of the national healthcare testing system, for which samples are analysed in one of 10 local clinical microbiology departments using RT-PCR or other nucleic acid amplification tests. The testing strategy is supplemented by an extensive antigen-testing programme, and persons with a positive antigen test are encouraged to get a confirmatory PCR test.

The Danish COVID-19 testing strategy includes asymptomatic testing for close contacts of confirmed cases and screening tests in certain settings (e.g. workplaces and primary schools). Overall, more than $15 \%$ of the Danish population is PCR-tested at least once during a week [3]. By 9 December, $9.2 \%$ of the Danish 
Timeline of SARS-CoV-2 Omicron developments, Denmark, November and December 2021

\begin{tabular}{|c|c|c|}
\hline Development & Date & Reference \\
\hline South Africa announces detection of a new SARS-CoV-2 variant B.1.1.529 & 25 November & [12] \\
\hline World Health Organization designates B.1.1.529 as a variant of concern, named Omicron & 26 November & [1] \\
\hline $\begin{array}{l}\text { Travel restrictions to South Africa and six neighbouring countries }{ }^{\mathrm{a}} \text { are put in place. This includes: } \\
\text { - Advice against travelling to these countries; } \\
\text { - For people with recent stays ( } \leq 10 \text { days) in these countries, testing within } 24 \mathrm{~h} \text { after arrival in Denmark and } \\
\text { isolation for } 10 \text { days; } \\
\text { - Restriction of travel without negative COVID-19 test; } \\
\text { - Incoming travellers from these countries are only allowed entry to Denmark with recognisable purpose and } \\
\text { when holding a negative COVID-19 testing certificate. }\end{array}$ & 27 November & [13] \\
\hline $\begin{array}{l}\text { First two Omicron cases confirmed by WGS in Denmark in returning travellers from South Africa; } \\
\text { Extensive contact tracing for Omicron cases implemented: } \\
\text { - Confirmed cases are to isolate until } 48 \mathrm{~h} \text { after symptom cessation } \\
\text { - Close contacts as well as close contacts of close contacts are recommended to quarantine regardless } \\
\text { of vaccination status and to take a PCR test on Days } 1,4 \text { and } 6 \text { from last exposure; recommendation of } \\
\text { quarantine until a negative result of the test on Day } 6 .\end{array}$ & 28 November & {$[14,15]$} \\
\hline Implementation of travel restrictions from three additional countries (Angola, Malawi and Zambia) & 29 November & [16] \\
\hline $\begin{array}{l}\text { All passengers arriving from Hamad International Airport, Qatar and Dubai International Airport, United Arab } \\
\text { Emirates, to be tested by antigen test at arrival in Denmark and referred to PCR test if the antigen test is } \\
\text { positive; } \\
\text { Omicron variant detection changes from del } 69-70 \text { to the more specific } 452 \mathrm{~L} \text {. }\end{array}$ & 1 December & [17] \\
\hline Change in the case definition of confirmed Omicron cases from WGS only to variant PCR and/or WGS & 4 December & [18] \\
\hline Quarantine requirement for close contacts of close contacts of Omicron cases is abolished. & 7 December & [19] \\
\hline
\end{tabular}

COVID-19: coronavirus disease; SARS-CoV-2: severe acute respiratory syndrome coronavirus 2; WGS: whole genome sequencing.

a Botswana, Eswatini, Lesotho, Mozambique, Namibia and Zimbabwe.

population had tested positive for SARS-CoV-2 since the start of the epidemic.

Surveillance of SARS-CoV-2 variants in Denmark is based on screening of all positive samples with variantspecific RT-PCR and extensive whole-genome sequencing (WGS) efforts. For most of 2021, more than $90 \%$ of SARS-CoV-2 isolates were sequenced, although rates have been lower since late autumn because of rising case numbers [4]. The TCDK has a maximum capacity of 15,000 WGS per week.

\section{Public health response to the Omicron variant}

An RT-PCR detecting the Omicron variant using the 452L marker (estimated specificity: $99.99 \%$ based on retrospective analysis) [5] was developed and implemented in the TCDK by 1 December. In the 10 local clinical microbiology departments, similar solutions have been set up. All isolates from cases who are found to be RT-PCR-positive for the Omicron variant are subsequently subjected to WGS. More WGS data are needed in order to have a meaningful positive predictive value. A confirmed Omicron case was defined based on WGS results until 3 December. From 4 December, the definition was extended to also include positive RT-PCR for the variant.

Extensive contact tracing around Omicron cases was initiated and is carried out by the Danish Patient Safety Authority (STPS). This includes self-isolation of cases until $48 \mathrm{~h}$ after symptom cessation for confirmed cases or, if asymptomatic, self-isolation for 7 days. It is recommended that all close contacts, as well as their close contacts, regardless of vaccination status, are tested (on Day 1, 4 and 6 after last contact with an Omicron case) and self-quarantine until a negative test result has been received after the final test on Day 6 . Self-quarantine of close contacts of close contacts was abolished on 7 December 2021. Restrictions on incoming travellers were introduced on 27 November (Table 1).

\section{Register-based surveillance}

To describe the Omicron cases, we used data from the routine Danish surveillance of COVID-19 [6] in which information from several national registries is linked daily. This provides information on demographic characteristics, vital status, vaccination status, previous SARS-CoV-2 infection, admission to hospital and intensive care treatment of cases. During contact tracing, 
Sample date for SARS-CoV-2 Omicron cases by suspected place of infection, Denmark, 22 November-7 December 2021, data as at 9 December $2021(n=785)$

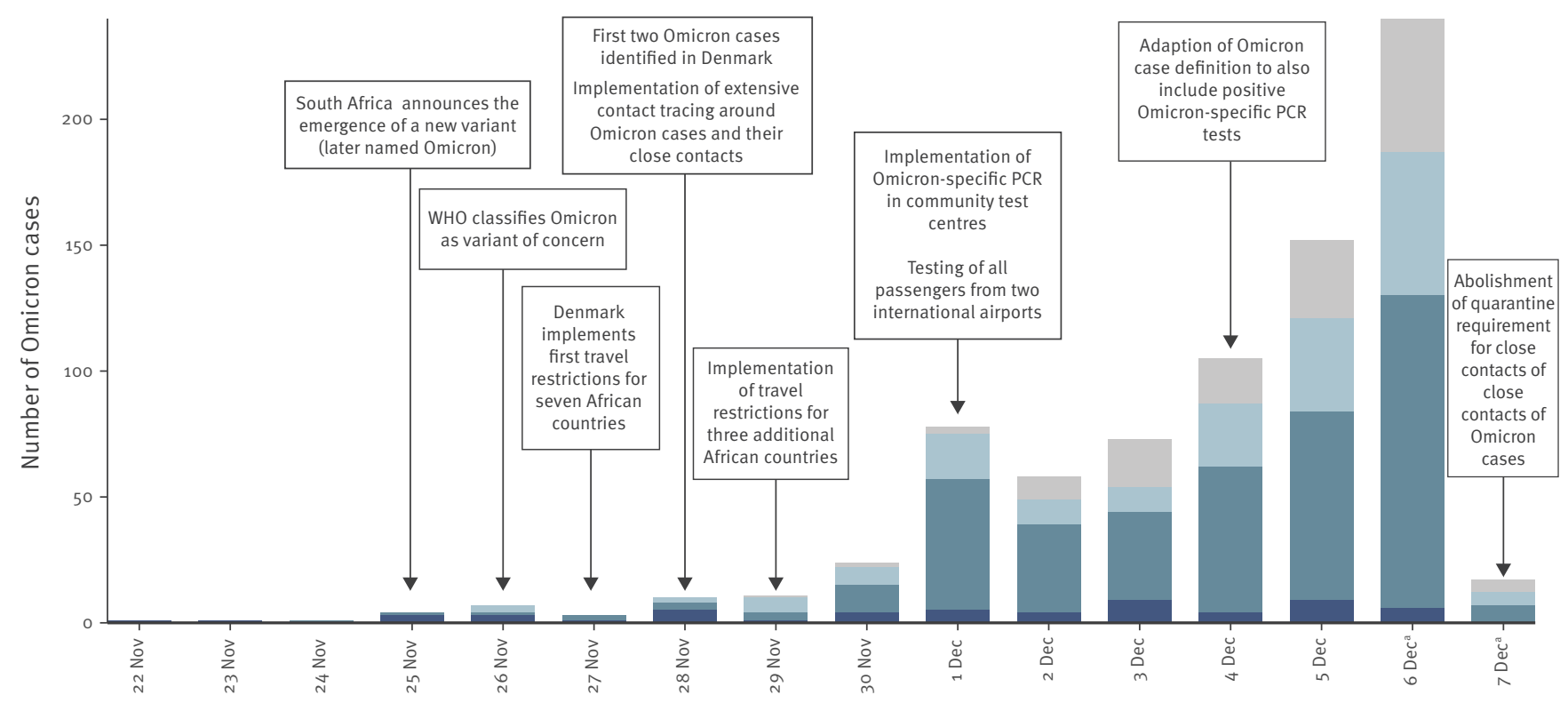

Date of sampling

\author{
Suspected place of infection \\ - Information from case follow-up pending \\ Denmark (unknown setting)
Denmark (known setting)
- Abroad

COVID-19: coronavirus disease; SARS-CoV-2: severe acute respiratory syndrome coronavirus 2; WGS: whole genome sequencing; WHO: World Health Organization.

${ }^{\text {a }}$ Note that the number of cases from 6 and 7 December is not fully representative as data are pending.

the STPS collects information on travel history symptoms and suspected place of infection.

\section{Characterisation of cases}

As per 9 December 2021, 785 cases of SARS-CoV-2 Omicron have been registered in Denmark. As there is a few days' lag from sampling to test result, the latest sampling date was 7 December. Daily case counts rose quickly (Figure 1), with daily increases of more than $40 \%$ from 4 December. In total, 143 (18\%) have so far been confirmed by WGS. The age of cases ranged between 2 and 95 years (median: 32 ) and 433 (55\%) were male (Table 2). Nine cases (1.2\%) are or have been hospitalised, one case so far has received intensive care treatment and no cases have died. Cases were identified widespread across the country, but most were clustered in two main epicentres in the western part of Denmark and in the area of the Capital. A total of 599 $(76 \%)$ cases were fully vaccinated and an additional $56(7.1 \%)$ had received full vaccination plus a booster dose. Number and proportions of cases with the SARSCoV-2 Delta variant (B.1.617.2 and sublineages) in the same period are also shown in Table 2 for reference.
As at 9 December, 644 cases had known information on place of infection ( $82 \%$ of all cases) and 56 of them (8.7\%) reported a travel history. Sixteen reported travelling from South Africa, but also other African and European countries were reported (Table 2). These introductions are apparent on the phylogenetic tree (Figure 2). In addition, 464 cases (75\%) reported a possible place of infection and 180 non-travellers (28\%) did not report a suspicion on where they had been infected. To date, STPS has linked at least 83 Omicron cases to five large events in Denmark ( $>100$ participants). The number of cases related to these events is expected to increase as testing and contract tracing are ongoing. A high attack rate was reported at one of the events, a seasonal gathering with 150 participants, where $71(47 \%)$ participants got infected. The SARS$\mathrm{CoV}-2$ Omicron variant was introduced to the gathering by a person who had been travelling to South Africa. This virus was further transmitted to three secondary schools and a concert with ca 2,000 participants in the same region, and subsequently to other events in other parts of Denmark. Furthermore, a hospital outbreak has been identified on a geriatric ward where at least 
TABLE 2

Characteristics of SARS-CoV-2 Delta and Omicron variant cases, Denmark, 22 November-7 December 2021

\begin{tabular}{|c|c|c|c|c|}
\hline & $\begin{array}{l}\text { Number of Delta }{ }^{a} \text { cases } \\
(n=19,137)\end{array}$ & $\%$ of all Delta ${ }^{a}$ cases & $\begin{array}{l}\text { Number of Omicron cases } \\
(n=785)\end{array}$ & $\begin{array}{c}\% \text { of all Omicron } \\
\text { cases }\end{array}$ \\
\hline \multicolumn{5}{|l|}{ Age (years) } \\
\hline $0-9$ & 3,081 & 16 & 30 & 3.8 \\
\hline $10-14$ & 2,434 & 13 & 23 & 2.9 \\
\hline $15-19$ & 962 & 5.0 & 102 & 13 \\
\hline $20-29$ & 2,317 & 12 & 214 & 27 \\
\hline $30-39$ & 2,548 & 13 & 110 & 14 \\
\hline $40-49$ & 2,973 & 16 & 111 & 14 \\
\hline $50-64$ & 2,952 & 15 & 144 & 18 \\
\hline$\geq 65$ & 1,870 & 10 & 51 & 6.5 \\
\hline \multicolumn{5}{|l|}{ Sex } \\
\hline Female & 9,637 & 50 & 352 & 45 \\
\hline Male & 9,500 & 50 & 433 & 55 \\
\hline \multicolumn{5}{|l|}{ Travel history } \\
\hline Yes $^{b}$ & \multicolumn{2}{|c|}{ NA } & 56 & 7.1 \\
\hline No & \multicolumn{2}{|c|}{ NA } & 601 & 77 \\
\hline Unknown & \multicolumn{2}{|c|}{ NA } & 128 & 16 \\
\hline \multicolumn{5}{|l|}{ Vaccination status $^{c}$} \\
\hline Not vaccinated & 8,199 & 44 & 111 & 14 \\
\hline Started $^{d}$ & 484 & 2.6 & 19 & 2.4 \\
\hline Vaccinated $^{\mathrm{e}}$ & 9,269 & 50 & 599 & 76 \\
\hline Booster vaccination $^{f}$ & 597 & 3.2 & 56 & 7.1 \\
\hline \multicolumn{5}{|c|}{ Previous SARS-CoV-2 infection confirmed by RT-PCR in Denmark } \\
\hline Yes & 160 & 0.9 & 34 & 4.3 \\
\hline No & 18,389 & 99 & 751 & 96 \\
\hline \multicolumn{5}{|c|}{ Self-reported symptoms } \\
\hline Yes & \multicolumn{2}{|c|}{ NA } & 509 & 65 \\
\hline No & \multicolumn{2}{|c|}{ NA } & 157 & 20 \\
\hline Unknown & \multicolumn{2}{|c|}{ NA } & 119 & 15 \\
\hline \multicolumn{5}{|l|}{ Hospitalisation } \\
\hline Yes & 290 & 1.5 & 9 & 1.2 \\
\hline \multicolumn{5}{|c|}{ Intensive care treatment } \\
\hline Yes & 22 & 0.11 & 1 & 0.13 \\
\hline \multicolumn{5}{|l|}{ Death } \\
\hline Yes & 14 & 0.07 & 0 & 0 \\
\hline
\end{tabular}

NA: not applicable; SARS-CoV-2: severe acute respiratory syndrome coronavirus 2.

a Based on WGS-confirmed cases with sampling date from 22 November-7 December 2021.

b South Africa $(n=16)$, Germany, Spain, Tanzania, Nigeria, Zimbabwe, United Kingdom, the Netherlands, Sweden and Belgium (sorted by frequency, only countries to which $\geq 2$ have reported travel is shown).

'Based on SARS-CoV-2 Delta variant cases from TCDK only $(n=18,549)$.

${ }^{\mathrm{d}}$ One dose but not yet completed vaccination schedule (see footnote ${ }^{\mathrm{e}}$ ).

e Vaccinated with two doses of Comirnaty (Pfizer/BioNTech, Mainz, Germany/ New York, United States), Vaxzevria (AstraZeneca, Cambridge, United Kingdom), Spikevax (Moderna, Cambridge, United States), or one dose of COVID-19 Vaccine Janssen (Johnson \& Johnson, New Brunswick, United States) at least 14 days before positive test. By 9 December $2021,76 \%$ of the Danish population had been fully vaccinated.

${ }^{f}$ Booster vaccination ca 6 months after being fully vaccinated and at least 14 days before positive test.

${ }^{g}$ Previous infection is defined as having a positive PCR tests more than 60 days from the current sample. 
Maximum-likelihood phylogeny for consensus genomes from SARS-CoV-2 Omicron cases sequenced in Denmark as at 7 December $2021(\mathrm{n}=92)$

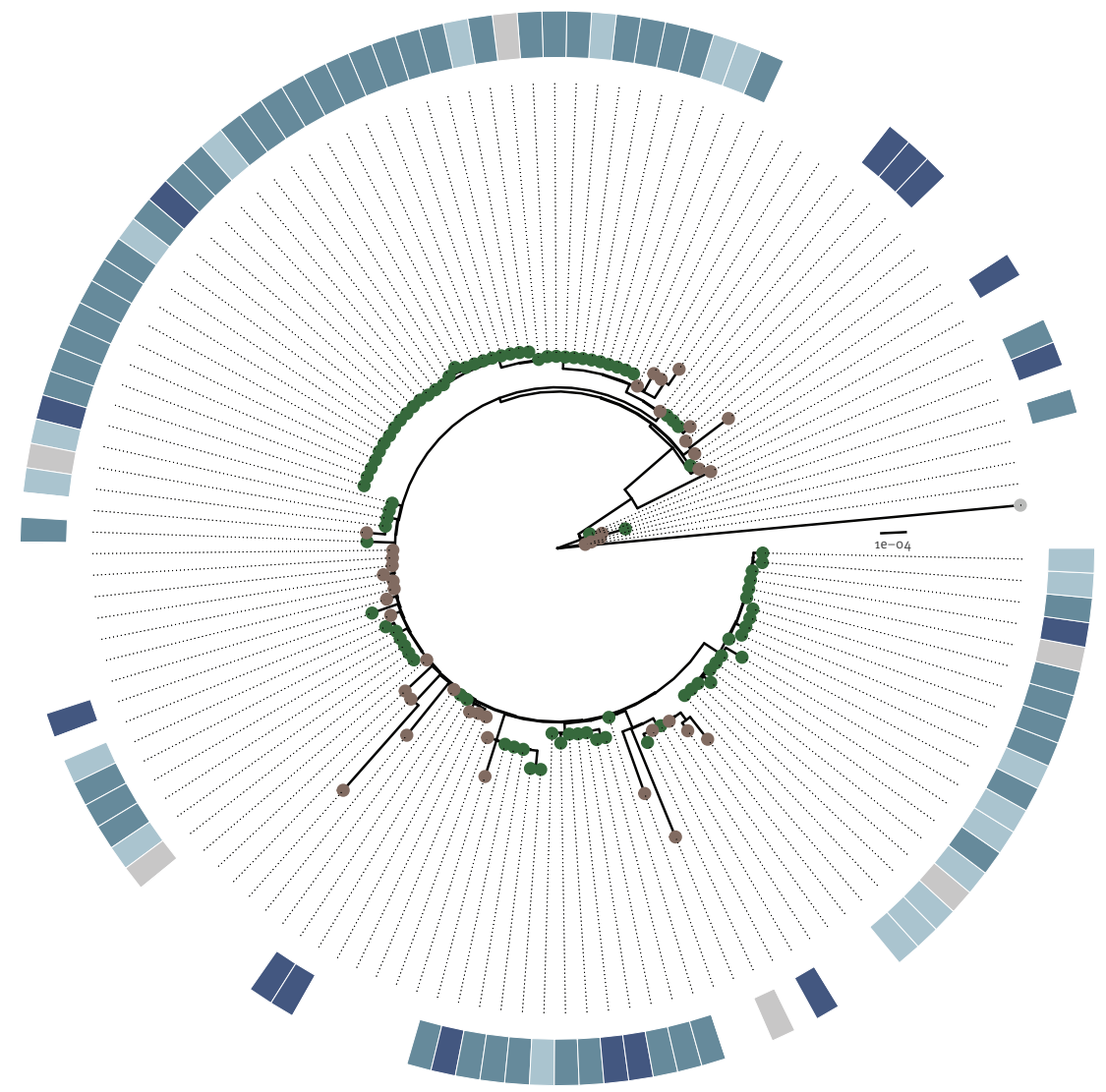

\author{
Suspected place of Infection \\ - Abroad \\ Denmark (known setting) \\ Denmark (unknown setting) \\ Information from case follow-up pending
}

Genome source

- Denmark

- GISAID

- Wuhan-Hu1

GISAID: Global initiative on sharing all influenza data; SARS-CoV-2: severe acute respiratory syndrome coronavirus 2.

Green nodes: Danish cases, showing suspected place of infection (heatmap); brown nodes: representative Omicron consensus genomes from the GISAID genome database not sequenced in Denmark (Supplementary Table S1), rooted on the Wuhan-Hu1 strain (grey node). Introductions are denoted in the heatmap as 'Abroad' [7-9].

four patients older than 80 years and two employees tested positive for Omicron. All of them were previously vaccinated.

\section{Ethical statement}

This study did not require ethical approval as it is based on routine surveillance data on COVID-19.

\section{Discussion}

Since the identification of the first Omicron case in Denmark, a steep increase in the number of cases has been observed. A major driver of this development was a large party with young adults - a population group with more social and close connections than adults and children. The rapid spread of the Omicron variant in Denmark is worrying, but not unexpected. On 2 December 2021, the European Centre for Disease Prevention and Control assessed a high probability of new introduction and community spread [10].
The response strategy in Denmark has been to delay transmission of the Omicron variant in order to gain time for roll-out of the third vaccine dose and the recently initiated vaccination programme for children aged 5 to 11 years. However, the rapid acceleration of cases catalysed by superspreading events challenged the mitigation. Despite the capacity to detect Omicron cases early, implementation of travel restrictions and implementation of extended contact tracing efforts, more than one in five cases cannot be linked to previous cases. This indicates that within 1.5 weeks from identifying the first case of Omicron, there is already widespread community transmission in Denmark, which challenges further epidemic control.

It is of concern that $83 \%$ of cases occurred in fully or booster-vaccinated people. Whether this observation is an artefact as the major superspreading events and subsequent chains of transmission have occurred primarily in young adults, and not yet spread to children, who have not been vaccinated, is still too early to 
say. The data are too immature to allow analysing the cases by vaccine type. However, it can be mentioned that $76 \%$ of the Danish population are fully vaccinated and $84 \%$ of these have received Comirnaty (Pfizer/ BioNTech, Mainz, Germany/ New York, United States) followed by $14 \%$ with Spikevax (Moderna, Cambridge, United States). The composition of cases as well as the short follow-up period may affect the observed proportion of hospitalised cases. The proportion of asymptomatic cases should be interpreted considering the massive testing of contacts and relatively quick followup of cases, which means that SARS-CoV-2 Omicron cases may be caught early in their course of infection, potentially before the development of symptoms.

Of note, the earliest Omicron cases in Denmark occurred before South Africa announced the emergence of this variant. These cases reported travel history from Qatar and the Netherlands, indicating that the variant might have spread from the African continent before this. Also, later Danish travel-related cases are not only found among travellers returning from South Africa but also from other European countries, indicating that community spread is likely to be more widespread than reported.

Denmark has one of the highest RT-PCR testing capacities in the world and screens all positive RT-PCR tests with an Omicron-specific PCR [11]. Linking this information with national registers allows us to give a detailed overview of the early spread of the Omicron variant. We find several reasons for concern: (i) the rapid spread shortly after introduction despite extensive contact tracing efforts, (ii) the occurrence of several superspreading events with high attack rates and (iii) the high proportion of fully vaccinated Omicron cases. We observed nine hospitalisations and one case needed intensive care treatment. Owing to limited follow-up time and few admissions, it is too early to conclude on the severity of the Omicron variant.

\section{Conclusion}

We show a rapid increase and spread of the SARS-CoV-2 Omicron variant in Denmark, a European country with high testing capacity, high vaccination coverage and limited natural immunity through SARS-CoV-2 infection. The introduction and spread occurred despite an early and comprehensive public health response. Spread was catalysed by superspreading events and challenges further epidemic control. Information from the earlier travel-related cases, with no travel history to Africa, suggests that community transmission is more widespread than reported. The high proportion of fully vaccinated Omicron cases is a concern, the implications are still being described. It is too early to draw conclusions on the severity of Omicron compared to previous SARS-CoV-2 variants, analyses on this are ongoing.
Acknowledgements

We would like to thank the following people for their tireless commitment in response around Omicron, working close to non-stop including weekends and nights: Rikke Thoft Nielsen, Katrine Finderup Nielsen, Louise Hallundbæk, Mie Agermose Gram, Pernille Kold Munch, Frederikke Kristensen Lomholt, Marianne Voldstedlund, Camilla Rasmussen, Nour Abushalleeh, Sophie Gubbels, Kirsten M. Ellegaard, Thor Bech Johannesen, Sharmin Baig and The Danish Covid-19 Genome Consortium (DCGC).

Supplementary Table S1 acknowledges the contributors of GISAID genomes used in this study.

Conflict of interest

None declared.

\section{Authors' contributions}

LE, LM and TF drafted the manuscript with all authors contributing by editing and conducting the laboratory analyses, data collection, curation and analyses. All authors read and approved the final version of the manuscript.

\section{References}

1. World Health Organization (WHO). Classification of Omicron (B.1.1.529): SARS-CoV-2 variant of concern. Geneva: WHO; 2021. Available from: https://www.who.int/news/item/26-112021-classification-of-omicron-(b.1.1.529)-sars-cov-2-variantof-concern

2. Statens Serum Institut (SSI). Covid-19 - Danmark (kommunalt). [COVID-19 Denmark (by municipality)]. Copenhagen: SSI. [Accessed: 9 Dec 2021]. Danish. Available from: https://experience.arcgis.com/experience/ aa41b29149f24e20a4007aoc4e13db1d/page/page_o

3. Statens Serum Institut (SSI). Covid-19 - Danmark (regionalt). [COVID-19 Denmark (by region)]. Copenhagen: SSI. [Accessed: 9 Dec 2021]. Danish. Available from: https://experience.arcgis. com/experience/aa41b29149f24e20a4007aoc4e13db1d/page/ page_3

4. Danish Covid-19 Genome Consortium. Genomic overview of SARS-CoV-2 in Denmark. Copenhagen: Statens Serum Institut. [Accessed: 14 December 2021]. Available from: https://www. covid19genomics.dk/statistics

5. Spiess K, Gunalan V, Marving E, Nielsen SH, Jørgensen MGP, Fomsgaard AS, et al. Rapid surveillance platforms for key SARS-CoV-2 mutations in Denmark. medRxiv. 2021:2021.10.25.21265484. Preprint. https://doi. org/10.1101/2021.10.25.21265484

6. Schønning K, Dessau RB, Jensen TG, Thorsen NM, Wiuff C, Nielsen L, et al. Electronic reporting of diagnostic laboratory test results from all healthcare sectors is a cornerstone of national preparedness and control of COVID-19 in Denmark. APMIS. 2021;129(7):438-51. https://doi.org/10.1111/apm.13140 PMID: 33949007

7. Katoh K, Standley DM. MAFFT multiple sequence alignment software version 7: improvements in performance and usability. Mol Biol Evol. 2013;30(4):772-8o. https://doi. org/10.1093/molbev/msto10 PMID: 23329690

8. Minh BQ, Schmidt HA, Chernomor O, Schrempf D, Woodhams $M D$, von Haeseler A, et al. IQ-TREE 2: New Models and Efficient Methods for Phylogenetic Inference in the Genomic Era. Mol Biol Evol. 2020;37(5):1530-4. https://doi.org/10.1093/molbev/ msaa015 PMID: 32011700

9. Li W, Godzik A. Cd-hit: a fast program for clustering and comparing large sets of protein or nucleotide sequences. Bioinformatics. 2006;22(13):1658-9. https://doi.org/10.1093/ bioinformatics/btl158 PMID: 16731699

10. European Centre for Disease Prevention and Control (ECDC). Threat assessment brief: Implications of the further emergence and spread of the SARS CoV 2 B.1.1.529 variant of concern (Omicron) for the EU/EEA first update. Stockholm: ECDC; 2021. Available from: https://www.ecdc.europa.eu/en/publications-data/ covid-19-threat-assessment-spread-omicron-first-update 
11. World map: total tests performed relative to the size of the population. Our World in Data. Accessed 15 December 2021. Available from: https://ourworldindata.org/coronavirustesting\#world-map-total-tests-performed-relative-to-the-sizeof-population

12. South African Institute for Communicable Diseases (NICD) Division of the National Health Laboratory Service. New COVID-19 variant detected in South Africa. Johannesburg: NICD; 2021. Available from: https://www.nicd.ac.za/ new-covid-19-variant-detected-in-south-africa

13. Sundhedsministeriet (Danish Ministry of Health). Danmark indfører indrejserestriktioner for syv lande i det sydlige Afrika. [Denmark introduces entry restrictions for seven countries in southern Africa]. Copenhagen: Sundhedsministeriet; 2021. Danish. Available from: https://sum.dk/nyheder/2021/ november/danmark-indfoerer-indrejserestriktioner-for-syvlande-i-det-sydlige-afrika

14. Statens Serum Institut (SSI). De to mistænkte tilfælde af coronavirus varianten Omicron i Danmark er nu bekræftet. [The two suspected cases of coronavirus variant Omicron in Denmark are now confirmed]. Copenhagen: SSI; 2021. Danish. Available from: https://www.ssi.dk/aktuelt/nyheder/2021/ de-to-mistaenkte-tilfaelde-af-coronavirus-varianten-omicron-idanmark-er-nu-bekraeftet

15. Sundhedsstyrelsen (Danish Health Authority). Nye skærpede retningslinjer for smitteopsporing ved smitte eller mistanke om smitte med den nye virusvariant Omicron. [New stricter guidelines for contact tracing in cases of infection or suspected infection with the new virus variant Omicron]. Copenhagen: Sundhedsstyrelsen; 2021. Danish. Available from: https://www.sst.dk/da/Nyheder/2021/ Nye-skaerpede-retningslinjer-for-smitteopsporing-Omicron

16. Sundhedsministeriet (Danish Ministry of Health). Danmark indfører skærpede rejserestriktioner for yderligere tre lande i det sydlige Afrika [Denmark introduces stricter travel restrictions for another three countries in southern Africa]. Copenhagen: Sundhedsministeriet; 2021. Danish. Available from: https://sum.dk/nyheder/2021/november/danmarkindfoerer-skaerpede-rejserestriktioner-for-yderligere-tresydafrikanske-lande

17. Sundhedsministeriet (Danish Ministry of Health).

Indrejsereglerne skærpes yderligere med krav om test ved ankomst fra udvalgte lufthavne. [Entry rules further tightened with requirement to test on arrival from selected airports]. Copenhagen: Sundhedsministeriet; 2021. Danish. Available from: https://sum.dk/nyheder/2021/december/ indrejsereglerne-skaerpes-yderligere-med-krav-om-test-vedankomst-fra-udvalgte-lufthavne

18. Statens Serum Institut (SSI). Status på omikron-varianten (B.1.1.529) pr. 05.12.21. [Status of the Omikron variant (B.1.1.529) on 5 Dec 2021]. Copenhagen: SSI; 2021. Danish. Available from: https://www.ssi.dk/aktuelt/nyheder/2021/ status-pa-omikron-varianten-b11529-pr-051221

19. Sundhedsstyrelsen (Danish Health Authority). Nære kontakters nære kontakter skal ikke længere gå i selvisolation. [Close contacts of close contacts no longer need to self-isolate]. Copenhagen: Sundhedsstyrelsen; 2021. Danish. Available from: https://www.sst.dk/da/Nyheder/2021/Naere-kontaktersnaere-kontakter-skal-ikke-laengere-gaa-i-selvisolation

\section{License, supplementary material and copyright}

This is an open-access article distributed under the terms of the Creative Commons Attribution (CC BY 4.0) Licence. You may share and adapt the material, but must give appropriate credit to the source, provide a link to the licence and indicate if changes were made.

Any supplementary material referenced in the article can be found in the online version.

This article is copyright of the authors or their affiliated institutions, 2021. 